\title{
COMPARISON BETWEEN CONVENTIONAL TUBE TECHNIQUE AND COLUMN AGGLUTINATION TECHNIQUE FOR ANTIBODY SCREENING AND IDENTIFICATION AT MGM BLOOD BANK, NAVI MUMBAI
}

\author{
Lakshita Varshney1, Seema Gupta²
}

${ }^{1}$ Resident, Department of Immunohaematology and Blood Transfusion, MGM Medical College and Hospital, Kamothe, Navi Mumbai. ${ }^{2}$ Associate Professor, Department of Immunohaematology and Blood Transfusion, MGM Medical College and Hospital, Kamothe, Navi Mumbai.

\begin{tabular}{l}
\hline ABSTRACT \\
BACKGROUND \\
Pretransfusion testing is one of the most important section of the entire transfusion process. Conventional tube technique (CTT) is \\
the most commonly employed technique in blood grouping, cross-matching and for the detection of antibodies. It is still considered \\
as a gold standard in the pretransfusion testing but it has some inherent limitations. Newer techniques have been introduced to \\
overcome the shortcomings of the CTT. One of them is Column agglutination technique (CAT). The present study was aimed to \\
evaluate the efficacy in terms of sensitivity and specificity of CAT over the CTT in our setup for antibody screening and \\
identification.
\end{tabular}

\section{MATERIALS AND METHODS}

The prospective comparative study was conducted for a period of 6 months. A total of 2258 patients' samples were screened for antibody detection during the pretransfusion testing process. Each sample was tested with CTT parallelly with CAT for antibody screening and identification. The results of CTT and CAT were compared using Student ' $\mathrm{t}$ ' test, $\mathrm{p}$ value of $<0.05$ was considered significant. The sensitivity and specificity were calculated by the standard manual method.

\section{RESULTS}

Out of 2258 samples screened, a total of 11 cases with antibodies were identified. Of these, all 11 could be identified by CAT and only 7 were determined by CTT. The overall incidence of alloimmunisation was $0.5 \%$. Out of 11 antibodies, 10 were clinically significant and one was clinically insignificant. The most commonly found antibody was Anti-D followed by Anti-c, Anti-M, AntiFy(a) and Anti-Le(a). The results obtained by CTT and CAT showed statistical significant difference, $p$ value $=0.04$. The sensitivity of CTT was $63.63 \%$ while the specificity was $100 \%$. The sensitivity and specificity of CAT were $100 \%$.

\section{CONCLUSION}

The gel technique is now considered better and has been introduced as a replacement to conventional tube technique on an automation platform. Though CTT is still considered gold standard in pretransfusion testing, it still has various disadvantages and depends on accurate hand to eye work of the laboratory personnel. The CAT, although being costly affair, still has several advantages over the tube technique. Therefore, it is highly recommended to be used routinely in the pretransfusion testing.

\section{KEYWORDS}

Pretransfusion Testing, Conventional Tube Technique, Column Agglutination Technique.

HOW TO CITE THIS ARTICLE: Varshney L, Gupta S. Comparison between conventional tube technique and column agglutination technique for antibody screening and identification at MGM blood bank, Navi Mumbai. J. Evolution Med. Dent. Sci. 2017;6(92): 6551-6555, DOI: $10.14260 /$ jemds/2017/1420

\section{BACKGROUND}

Pretransfusion testing is one of the most important section of the entire transfusion process. ${ }^{1} \mathrm{ABO}$ and $\mathrm{Rh}$ blood grouping, cross- matching between donor and recipient and antibody screening and identification to detect clinically significant antibodies are the basic steps of the pretransfusion testing in blood banking. ${ }^{2}$ Antibody screening and identification tests are performed to detect "irregular" or "unexpected" antibodies, as opposed to the "expected" antibodies of the ABO system in recipients' serum.3,4

'Financial or Other Competing Interest': None.

Submission 21-10-2017, Peer Review 15-11-2017,

Acceptance 21-11-2017, Published 04-12-2017.

Corresponding Author:

Dr. Lakshita Varshney,

C-2/119A, Lawrence Road,

Keshav Puram

Delhi-110035.

E-mail: lakshita1989v@gmail.com

DOI: $10.14260 /$ jemds $/ 2017 / 1420$

These are the principle tools to select compatible blood for recipients to prevent haemolytic transfusion reactions and alloimmunisation.

Conventional tube technique (CTT) is the most commonly employed technique in blood grouping, cross-matching and for the detection of antibodies. It is still considered as a gold standard in the pretransfusion testing but it has some inherent limitations like multiple washing steps, the instability of the reactions and subjective nature of grading by the technologist, etc. However, in the recent years, newer techniques have been introduced which have not only tried to overcome the shortcomings of the conventional tube technique but have also showed substantial improvement in the quality of results.5,6 One of the newer technique is Column agglutination technique (CAT) which is also known as Micro typing gel method. It is based on the principle of controlled centrifugation of RBCs through dextran acrylamide gel that contained predispensed reagents. This gel column agglutination test was developed by Dr. Lapierre in 1985 who 
used Sephadex gel within the microtube. ${ }^{7}$ This gel technique is advantageous in being simple, less labour intensive, offers consistent and objective stable results. It requires small amount of sample volume and it includes no washing steps or controls for antiglobulin tests. 5,6

Therefore, the present study was carried out to evaluate the efficacy in terms of sensitivity and specificity of Micro typing gel method over the conventional tube method in our setup for antibody screening and identification

\section{MATERIAL AND METHODS}

The prospective comparative study was conducted in the Department of Immunohaematology and Blood Transfusion, MGM Medical College and Hospital, Kamothe, Navi Mumbai for a period of 6 months from January 2017 to June 2017. A total of 2258 patients' samples were screened for antibody detection during the pretransfusion testing process. Anticoagulated EDTA (ethylenediaminetetraacetic acid) and clotted (plain) samples were used for testing. Each sample was tested with Conventional Tube technique (CTT) and Column agglutination technique (CAT) for antibody screening and identification. The study was approved by Institutional ethical committee.

\section{Conventional Tube Technique}

It was performed by taking $25 \mu \mathrm{L}$ of red cell suspensions [IDDiaCell I-II-III, Biorad, Diamed, Switzerland] and $50 \mu \mathrm{L}$ of patient's serum sample. They were mixed and kept for incubation at $37^{\circ} \mathrm{C}$ for $60 \mathrm{~min}$. Then they were centrifuged and the results were noted. If negative, the tubes were washed three times with normal saline and polyspecific Antihuman globulin reagent, AHG (Diaclon Coombs, Diamed, Switzerland) was added. After centrifugation, the results were noted. The procedure was in accordance with the standard method described by AABB. ${ }^{8}$ The samples coming positive on screening cells were then subjected to identification panel cells [ID-DiaPanel (11 cell), Biorad, Diamed, Switzerland]. The negative tests after AHG phase were validated by presence of agglutination on addition of Coomb's control cells (in-house). All reactions were graded and recorded.

\section{Column Agglutination Technique}

It was performed by adding $50 \mu \mathrm{L}$ of red cell suspension [IDDiaCell I-II-III, Biorad, Diamed, Switzerland] in low ionic strength solution (LISS) to appropriately labelled microtube of the ID cards (polyspecific AHG, LISS Coombs card, Diamed, Switzerland). Then, $25 \mu \mathrm{L}$ of patient's sample was added in each microtube of Id-Cards. After incubation at $37^{\circ} \mathrm{C}$ for 15 min., they were centrifuged in a dedicated centrifuge device (Diamed, Switzerland). Samples reactive with screen cells were then similarly tested for identification panel cell [IDDiaPanel (11 cell), Biorad, Diamed, Switzerland]. The findings were graded and documented. The gel technique was performed following manufacturer's instruction.

\section{Statistical Analysis}

The statistical analysis was done using Microsoft excel. The results of Conventional tube technique and column agglutination technique were compared using Student ' $\mathrm{t}$ ' test, $p$ value was calculated and a value of $<0.05$ was considered significant. The sensitivity and specificity, positive predictive value and negative predictive value were calculated by the standard manual method. On theoretical basis, conventional tube technique in AHG phase was assumed as standard reference for sensitivity and specificity. $1,4,5$

\section{RESULTS}

During the 6-month study period, 2258 samples were screened with conventional tube technique in parallel with column agglutination technique. Out of 2258, 1027 (45.48\%) were males and 1231 (54.51\%) were females. The mean age of the patients was 27.90 years. The age distribution of the patients is summarised in Table 1.

\begin{tabular}{|c|c|c|}
\hline $\begin{array}{c}\text { Age Group } \\
\text { (In Years) }\end{array}$ & $\begin{array}{c}\text { No. of Patients } \\
\text { (N) }\end{array}$ & N\% \\
\hline $0-10$ & 241 & 10.67 \\
\hline $11-20$ & 524 & 23.20 \\
\hline $21-30$ & 683 & 30.24 \\
\hline $31-40$ & 387 & 17.13 \\
\hline $41-50$ & 158 & 6.99 \\
\hline $51-60$ & 96 & 4.25 \\
\hline $61-70$ & 93 & 4.11 \\
\hline $71-80$ & 76 & 3.36 \\
\hline Total & 2258 & 100 \\
\hline \multicolumn{2}{|c|}{ Table 1. Age Distribution of Patients } \\
\hline
\end{tabular}

A total of 11 cases with antibodies were identified. Of these, all 11 were identified by Column agglutination method (CAT) and only 7 were determined by conventional tube technique (CTT). The overall incidence of alloimmunisation was $0.5 \%$. Antibody specificity was not associated with age and sex of the patient. Table 2 shows comparison of the results by conventional tube technique and column agglutination technique.

\begin{tabular}{|l|c|c|}
\hline Result & CTT & CAT \\
\hline Positive & $7(63.63 \%)$ & $11(100 \%)$ \\
\hline Negative & $4(36.36 \%)$ & $0(0 \%)$ \\
\hline \multicolumn{3}{|c|}{ Table 2. Comparison of the Results Obtained by } \\
CTT and CAT \\
\hline
\end{tabular}

Out of 11 cases, 10 were clinically significant and 1 clinically insignificant. Table 3 and Figure 1 summarises the results obtained by both techniques which determines the number of antibodies.

\begin{tabular}{|c|c|c|}
\hline $\begin{array}{c}\text { Antibody } \\
\text { Identified }\end{array}$ & $\begin{array}{c}\text { Column } \\
\text { Agglutination } \\
\text { Technique (CAT) }\end{array}$ & $\begin{array}{c}\text { Conventional } \\
\text { Tube Technique } \\
\text { (CTT) }\end{array}$ \\
\hline \multicolumn{3}{|c|}{ Clinically Significant Antibodies } \\
\hline Anti-D & 7 & 5 \\
\hline Anti-c & 1 & 1 \\
\hline Anti-M & 1 & 1 \\
\hline Anti-Fy (a) & 1 & 0 \\
\hline \multicolumn{2}{|c|}{ Clinically Insignificant Antibodies } \\
\hline Anti-Le (a) & 1 & 0 \\
\hline \multicolumn{2}{|c|}{ Total } & $\mathbf{1 1}$ \\
\hline
\end{tabular}

Table 3. Number of Antibodies Identified by CAT and CTT 


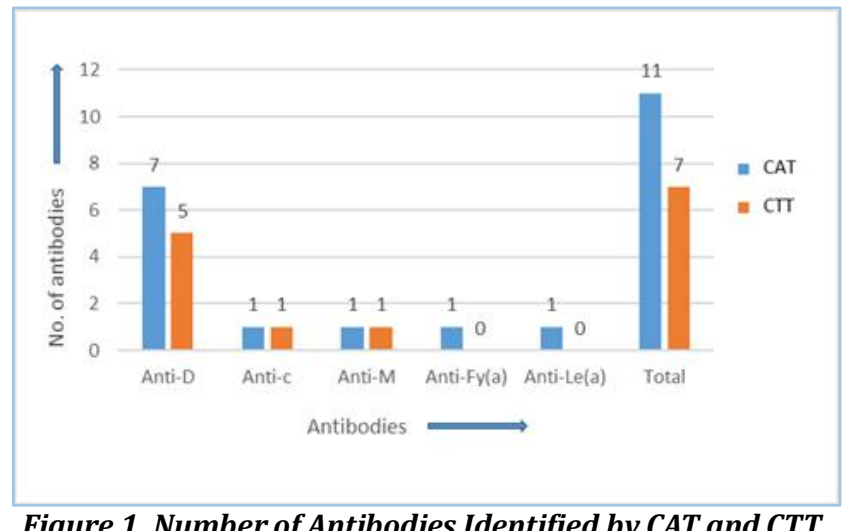

\section{Figure 1. Number of Antibodies Identified by CAT and CTT}

Column agglutination technique detected all 10 clinically significant antibodies and one clinically insignificant antibodies. Conventional tube technique detected 7 clinically significant antibodies when proceeded to anti-human globulin phase but failed to detect other clinically significant and insignificant antibodies. Out of 11 cases of alloantibodies, 7 cases of anti-D were detected in multigravida females with $\mathrm{Rh} \mathrm{D}$ negative blood groups, 1 case of anti-c and anti-M each were identified in thalassaemia patients, 1 case of anti-Fy(a) was a patient who received multiple transfusions for cardiac surgery and 1 case of Le(a) was a patient who received multiple transfusions for refractory anaemia. [Table 4 and Figure 2].

\begin{tabular}{|c|c|c|c|}
\hline $\begin{array}{c}\text { Antibody } \\
\text { Identified }\end{array}$ & $\begin{array}{c}\text { Indication for } \\
\text { Transfusion }\end{array}$ & $\begin{array}{c}\text { No. of } \\
\text { Antibodies } \\
\text { (N) }\end{array}$ & $\begin{array}{c}\text { No. of } \\
\text { Antibodies } \\
\text { (N \%) }\end{array}$ \\
\hline Anti-D & $\begin{array}{c}\text { Multigravida } \\
\text { females }\end{array}$ & 7 & $63.63 \%$ \\
\hline Anti-c & Thalassaemia & 1 & $9.08 \%$ \\
\hline Anti-M & Thalassaemia & 1 & $9.08 \%$ \\
\hline Anti-Fy(a) & $\begin{array}{c}\text { Multiple } \\
\text { transfusions for } \\
\text { cardiac surgery }\end{array}$ & 1 & $9.08 \%$ \\
\hline Anti-Le(a) & $\begin{array}{c}\text { Multiple } \\
\text { transfusions for } \\
\text { refractory } \\
\text { anaemia }\end{array}$ & 1 & $9.08 \%$ \\
\hline \multicolumn{3}{|c|}{ Total Table 4. Antibodies Identified with Indication of } \\
\hline \multicolumn{4}{|c|}{\begin{tabular}{c} 
Transfusion \\
\hline
\end{tabular}} \\
\hline
\end{tabular}

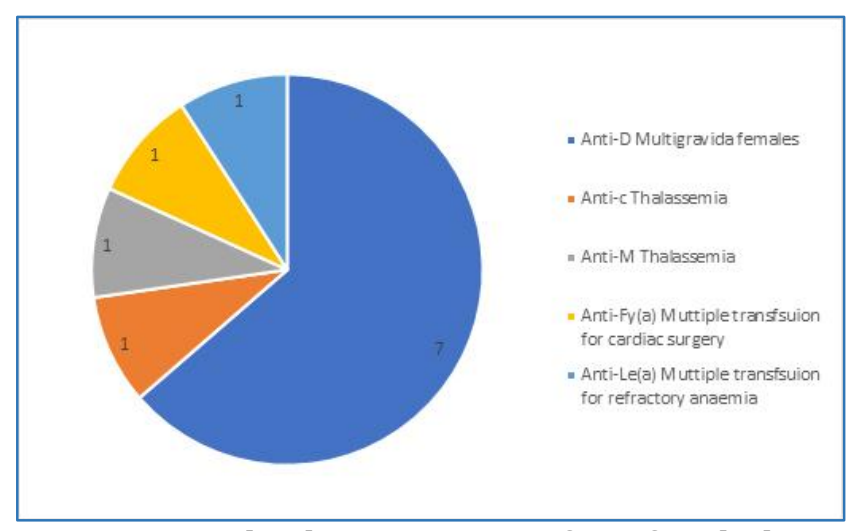

Figure 2. Graphical Representation of No. of Antibodies Identified with Indication of Transfusion
On statistical analysis, the results obtained by conventional tube technique and column agglutination method showed statistical difference, $p$ value $=0.04$, which was significant $(\mathrm{p}<0.05)$. The sensitivity of determining antibodies by Conventional tube technique was $63.63 \%$ while the specificity was $100 \%$. The sensitivity and specificity of determining antibodies by column agglutination method were $100 \%$ each. The positive predictive value and negative predictive value for conventional tube technique were $100 \%$ and $99.8 \%$ respectively, while for column agglutination technique, the positive and negative predictive values were found to be $100 \%$ each.

\section{DISCUSSION}

Cross-matching as a part of pretransfusion testing is performed in all blood centres before transfusion to prevent alloimmunisation. The main aim of cross-matching is to detect clinically significant antibodies to the maximum. Since the introduction of concept of cross-matching, rationale has been changing from time to time. One of them is type and screen policy, which is widely practised in western countries but only few centres in developing countries in India have been working on it to make a part of their protocols. Red cell antibodies screening is important as these antibodies when clinically significant mediate haemolytic transfusion reactions or haemolytic disease of new-born and foetus. 9,10

At present, there are various methods of antibody screening available in various blood centres. They are Conventional Tube Technique (CTT), LISS-IAT, Column agglutination Technique (CAT), polyethylene glycol (PEG) tube test, solid phase red cell adherence assay (SPRCA) etc. ${ }^{11}$ We compared the commonly used techniques in our setup, the conventional tube technique and column agglutination technique also called as Micro typing gel technique. During the 6-month study period, 2258 samples were screened with most of the patient group lying between the age group 21-30 years (30.24\%).

A total of 11 alloantibodies were identified in 2258 patients during the study period making overall alloimmunisation rate to $0.5 \%$. This was comparable to the study by Pathak $\mathrm{S}$ et al ${ }^{10}$ which reported an overall rate of alloimmunisation of $1.5 \%$ in 45,373 patients. These frequencies were low as compared to $2.71 \%$ in 4569 patients and $5.5 \%$ in 200 patients reported by Agarwal A et al 12 and Philip J et al. ${ }^{13}$ Therefore, the reported prevalence of alloimmunisation in multi-transfused patients in India varies from approximately $3 \%$ to $10 \%{ }^{14,15,16}$ The rate of alloimmunisation globally was variable with $1.35 \%$ in Denmark, ${ }^{17} 0.78 \%$ in Germany, 18 and $0.3-2 \%$ in the USA ${ }^{19,20}$ to $21.1 \%$ in Greece, 21 30\% in Kuwait ${ }^{22}$ and $37 \%$ in Taiwan. ${ }^{23}$

The most commonly found clinically significant antibody in our study was Anti-D (7 out of 11 cases) followed by one case each of Anti-c, Anti-M, Anti-Fy(a). One case of clinically insignificant antibody was also identified, Anti-Le(a). Similar set of antibodies frequencies were reported in studies by Pathak $\mathrm{S}$ et $\mathrm{al}^{10}(\mathrm{Rh}>\mathrm{MNS}>\mathrm{Kell})$ and Philip $\mathrm{J}$ et al. $^{13}$ (Rh $>$ MNS $>$ Lewis). We found multigravida females followed by thalassaemia as the most common alloimmunised cases which was comparable to the study by Patel et al. ${ }^{24}$

Out of the 11 cases of alloantibodies identified, Column agglutination technique could identify all 11 cases while conventional tube technique identified 7 cases. These 7 cases 
identified by conventional tube technique were 5 cases of Anti-D, one case each of Anti-c and Anti-M while the other antibody cases were not detected by it. The number of antibodies detected by both the methods showed significant statistical difference $(\mathrm{p}<0.05)$. This was also demonstrated by specificity and sensitivity calculated for both techniques for determining potentially significant antibodies. The sensitivity of conventional tube technique was $63.63 \%$ and specificity was $100 \%$ while the sensitivity and specificity were $100 \%$ for column agglutination technique. Our findings were in accordance with the other studies of Swarup D. et al,25 Reis et $\mathrm{al}^{26}$ and Pinkerton et $\mathrm{al}^{27}$ where these techniques were compared.

Our study demonstrated that the results by conventional tube technique were comparable to column agglutination technique when subjected to IAT phase like the study by Swarup D. et al.25 The gel technique in our study could also identify cold reacting antibody, Anti-Le(a) apart from warm reacting antibodies. The detection of cold reacting antibodies was demonstrated in the past studies also by Lapierre et al, 7 Bromilow et $\mathrm{al}^{28}$ and Kretschmer et al. ${ }^{29}$ Therefore, gel technique is considered better than column agglutination technique. There are lower chances of false positive or false negative results by gel technique because there is increased serum to cell ratio with no washing step, thereby reducing possibility of elution of weakly bound antibodies from red blood cells. ${ }^{28}$ The time taken by gel technique procedure is 15-20 min. compared to tube technique procedure which is about 45-60 min. The sensitivity, specificity, positive predictive value and negative predictive value were found better for column agglutination technique on comparing with conventional tube technique which was comparable to other studies. 1,2,9,25,30,31 Column agglutination technique is, therefore, simple, rapid, more sensitive and helps in standardisation of laboratory results with objective haemagglutination findings. ${ }^{32}$ The only limitation is the cost of gel cards and commercial screening panel. In all blood centres, due to high costs per test it is very difficult to screen each and every patient for antibodies by gel technique and commercial screening panels. Though being the most sensitive way to detect alloantibodies, many blood centres are still reliant upon screening done by in-house prepared pooled cells which may not cover all antigens in tube technique.

In addition to antibody identification, various studies have shown that column agglutination technique gives better and accurate results in $\mathrm{ABO}$ and $\mathrm{Rh}$ grouping, dilutional titration and in evaluation of DAT (Direct antiglobulin test) when compared to conventional tube technique.

\section{CONCLUSION}

In the recent years, with advancement in blood banking, column agglutination technique has been introduced as a replacement to conventional tube technique on an automation platform. ${ }^{3}$ Though conventional tube technique is still considered gold standard in pretransfusion testing, it still has various disadvantages and depends on accurate hand to eye work of the laboratory personnel. The column agglutination technique on other hand, although being costly affair, still has several advantages over the tube technique.
Therefore, it is highly recommended to be used routinely in the pretransfusion testing.

\section{REFERENCES}

[1] Bhagwat SN, Sharma JH, Jose J, et al. Comparison between conventional and automated techniques for blood grouping and crossmatching: experience from a tertiary care centre. J Lab Physicians 2015;7(2):96102.

[2] Mehta N, Chakraborty IR, Rane M, et al. Verification of column agglutination technology with conventional tube technology for naturally occurring antibody titration. Glob J Transfus Med 2016;1(2):46-50.

[3] Kitpoka P, Suksomboonvong P, Chongkolwatana V, et al. Comparison of microcolumn agglutination test for blood group typing and antibody screening. J Hematol Transfus Med 2014;24:7-16.

[4] Harmening D. Modern blood banking and transfusion practices. Chapter 9. Detection and identification of antibodies, other technologies and automation. $6^{\text {th }}$ edn. Philadelphia, USA: FA Davis Company 2012:21640.

[5] Bajpai M, Kaur R, Gupta E. Automation in immunohematology. Asian J Transfus Sci 2012;6(2):140-4.

[6] Rumsey DH, Ciesielski DJ. New protocols in serologic testing: a review of techniques to meet today's challenges. Immunohematology 2000;16(4):131-7.

[7] Lapierre, Y, Rigal D, Adams J, et al. The gel test: a new way to detect red cell antigen-antibody reactions. Transfusion 1990;30(2):109-13.

[8] Fung MK, Grossman B, Hillyer C, et al. Technical Manual. 18 ${ }^{\text {th }}$ edn. Bethesda, MD, AABB 2014.

[9] Garg S, Saini N, Bedi RK, et al. Comparison of micro column technology with conventional tube methods for antibody detection. Journal of Laboratory Physicians 2017;9(2):95-9.

[10] Pathak S, Chandrashekhar M, Wankhede GR. Type and screen policy in the blood bank: Is AHG cross-match still required? A study at a multispecialty corporate hospital in India. Asian Journal of Transfusion Science 2011;5(2):153-6.

[11] Casina TS. In search of the Holy Grail: comparison of antibody screening methods. Immunohematology 2006;22(4):196-202.

[12] Agrawal A, Mathur A, Dontula S, et al. Red Blood Cell Alloimmunization in Multi - transfused patients: a Bicentric Study in India. Glob J Transfus Med 2016;1(1):12-5.

[13] Phillip J, Biswas AK, Hiregoudar S, et al. Red blood cell alloimmunization in multitransfused patients in a tertiary care center in Western India. Lab Med 2014;45(4):324-30.

[14] Lamba DS, Kaur R, Basu S. Clinically significant minor blood group antigens amongst North Indian donor population. Article ID 215454, Adv Hematol 2013;2013: p. 5.

[15] Shukla JS, Chaudhary RK. Red cell alloimmunization in multi-transfused chronic renal failure patients undergoing hemodialysis. Indian J Pathol Microbiol 1999;42(3):299-302. 
[16] Sood R, Makroo RN, Riana V, et al. Detection of alloimmunization to ensure safer transfusion practice. Asian J Transfus Sci 2013;7(2):135-9.

[17] Skov F, Ericksen M, Hagerup L. Distribution of the ABO, MNS, P, Rhesus, Lutheran, Kell, Lewis and Duffy blood groups and frequency of irregular red cell antibodies in a population of Danes aged fifty years and a population of Danes aged seventy years. From the Glostrup population studies. Acta Pathol Microbiol Scand B Microbiol Immunol 1970;78(5):553-9.

[18] Spielmann W, Seidl S. Prevalence of irregular cell antibodies and their significance in blood transfusion and antenatal care. Vox Sang 1974;26:551-9.

[19] Giblett ER. Blood group all antibodies: an assessment of some laboratory practices. Transfusion 1977;17(4): 299-308.

[20] Boral LI, Henry JB. The type and screen: a safe alternative and supplement in selected surgical procedures. Transfusion 1977;17(2):163-8.

[21] Spanos T, Karageorga M, Ladis V, et al. Red cell alloantibodies in patients with thalassemia. Vox Sang 1990;58(1):50-5.

[22] Ameen R, Al-Shemmari S, Al-Humood S, et al. RBC alloimmunization and autoimmunization among transfusion-dependent Arab thalassemia patients. Transfusion 2003;43(11):1604-10.

[23] Wang LY, Liang DC, Liu HC, et al. Alloimmunization among patients with transfusion-dependent thalassemia in Taiwan. Transf Med 2006;16(3):200-3.
[24] Patel J, Shukla R, Gupte S. Red cell alloimmunization in multitransfused patients and multiparous women. Indian J Hematol Blood Transfus 2009;25(2):49-52.

[25] Swarup D, Dhot PS, Kotwal J, et al. Comparative study of blood cross matching using conventional tube and gel method. MJAFI 2008;64(2):129-30.

[26] Reis KJ, Chachowski R, Cupido A, et al. Column agglutination technology: the antiglobulin test. Transfusion 1993;33(8):639-43.

[27] Pinkerton PH, Ward J, Chan R, et al. An evaluation of a gel technique for antibody screening compared with a conventional tube method. Transfus Med 1993;3(3):201-5.

[28] Bromilow IM, Adams KE, Hope J, et al. Evaluation of the ID-gel test for antibody screening and identification. Transfus Med 1991;1(3):159-61.

[29] Kretschmer V, Heuckeroth A, Schulzki T, et al. Superiority of gel centrifugation in antibody screening and identification. Infusionsther Transfusionsmed 1992;19(5):226-30.

[30] Das SS, Chaudhary R, Khetan D. A comparison of conventional tube test and gel technique in evaluation of direct antiglobulin test. Hematology 2007;12(2):175-8.

[31] Novaretti MC, Jens E, Pagliarini T, et al. Comparison of conventional tube test technique and gel microcolumn assay for direct antiglobulin test: a large study. J Clin Lab Anal 2004;18(5):255-8.

[32] Bromilow IM. Gel Techniques in blood group serology. Med Lab Sci 1992;49(2):129-32. 